\title{
The true revolutionary is guided by a great feeling of love: A remembrance for Ananth Aiyer
}

Dear DA readers,

You are all invited to attend "The true revolutionary is guided by a great feeling of love": A remembrance for Ananth Aiyer.

This is a special event, sponsored by the Society for the Anthropology of North America (SANA). It will take place Friday, November 20, from 7:45 p.m. to 9 p.m., at the annual meetings of the American Anthropological Association, in Denver, Colorado-specific location details will be made available in the conference program and on the Dialectical Anthropology website.

The event honors the life and work of Ananth Aiyer, who died in March 2015. At the time of his death, Aiyer was Associate Professor and Department Chair of Sociology, Anthropology and Criminal Justice in the College of Arts and Sciences at the University of Michigan-Flint. He was also co-editor of Dialectical Anthropology.

Aiyer's scholarly work focused on political economy and inequality in Latin America and India. Beloved by many, this event celebrates Aiyer's contributions to anthropology with comments by Winnie Lem, Anthony Marcus, David Nugent, Kathy Powell and Gavin Smith and by members of the audience.

I hope to see you all there.

Sincerely, Jeff Maskovsky 